migrate are often annihilated, without in any way eliminating the impulse in the species when the disadvantageous circumstances which caused it recur.

The emphasis on migration rather hides the fact that every free living animal has in the small affairs of its life a considerable amount of freewill. Examples are given, all from air living animals, but we think they would be easier to understand and found to be even stronger in aquatic forms. The third part is really an examination of these views with regard to the current conceptions of evolution. The idea of all structure in animals having an adaptive relation to the environment is surely out of date amongst zoologists, as also is the formation of species by natural selection by the accumulation of small variations. The whole question of mutations arises, and we agree that "without the aid of any adaptive advantage" such will never be able to spread beyond a certain point. But, if mutation has once occurred, the potentiality is there in the species and it may often reappear. We do not propose to follow the author in his discussion. We content ourselves with thanking him for indicating many sides of the study of living animals that may be pursued with advantage.

J. S. G.

The Heavens and the Universe. By Prof. Oswald Thomas. Translated by Bernard Miall. Pp. 288.

(London : George Allen and Unwin, Ltd., 1930.) $7 s .6 \mathrm{~d}$. net.

THIs book has been written by a star-lover for starlovers. It is couched in simple, conversational language, suitable for the earnest but not very learned mind. The author has for many years been accustomed to conducting night excursions into the woods near Vienna for the purpose of observing and studying the heavens, and he here tries to extend the usefulness of his talks to a wider circle. He has done very well. The book will appeal to the many persons whose interest in the sky will always be primarily a sentimental one, but who, nevertheless, feel a desire to know something of what the astronomer by his cold, intellectual inquiry has been able to discover. Prof. Thomas tells him this in a way which he will appreciate; the style is humane without undue preciosity. Anecdotes are common and usually to the point, and the illustrations have been successfully conceived.

The professional astronomer will probably meet with statements which will seem to call for criticism, but if he is wise enough to remember the purpose of the book he will turn a deaf ear to them. They are, in any case, few and of little significance, and the negative virtue of freedom from inaccuracy counts for little beside the many positive virtues which characterise the book. The translation-which achieves the merit of not being recognisable as such-is very satisfactory. Prof. Thomas's book is possibly the only popular astronomy which contains no photographic illustration. This, it must be confessed, is a defect, but the reader will probably have become so familiar with some of the admirable celestial photographs now available in such a variety of ways that the disadvantage will be reduced to a minimum.

Intermediate Mechanics. By D. Humphrey. Vol. 2: Statics and Hydrostatics. (Longmans' Modern Series.) Pp. xi +438 . (London, New York and Toronto : Longmans, Green and Co., Ltd., 1931.) 10s. $6 d$.

THIS very competently written volume, designed to cover " all requirements up to Higher Certificate and University Scholarships standard ", leaves one with a dream-like feeling that the Saturnian days of the old Cambridge mathematics have not yet passed away. Here are no philosophic doubts concerning the definitions of force and matter; a balance must still be (i) true, (ii) sensitive, (iii) stable, and (iv) rigid; the conventional systems of pulleys are carefully and clearly explained, with illustrative examples of every degree of ingenuity, and not so much as a picture of a Spanish Barton; and all our old problems concerning rods in bowls, jointed rhombuses, slipping ladders, sliding rings, jamming drawers, and examples of practically every type of question that the perverted imagination of an examiner can suggest, are assembled under their due headings and worked out in clear and orderly fashion. The book expands beyond the limits usually assigned to such work in well-written and fully illustrated chapters on beams and catenary problems, on graphical statics, and on virtual work.

There is no doubt that the book will provide all the guidance necessary for candidates taking examinations of the Intermediate standard, and will serve as a useful introduction to more advanced work. Whether books of this type are of real assistance in the training of engineers or of mathematicians is a matter concerning which we do not express any opinion.

A. F.

\section{A Compilation of Culture Media for the Cultivation} of Micro-organisms. By Prof. Max Levine and H. W. Schoenlein. (Monographs on Systematic Bacteriology.) Prepared at the request of the Society of American Bacteriologists and financed by a Grant from the Digestive Ferments Company, Detroit, Michigan. Pp. xvi +969. (London : Baillière, Tindall and Cox, 1930.) 67s. $6 d$. net.

THIs large volume is a compilation of various media used for the cultivation of bacteria, yeasts, and moulds. In all, about seven thousand have been assembled. These have been subdivided primarily into groups on the basis of physical characteristics and the nature of the solidifying agent used, and secondarily upon the chemical characteristics of the media. The use of each medium is indicated.

The book is one of a series of monographs on systematic bacteriology and was prepared at the request of the Society of American Bacteriologists. References are given with each medium, and an excellent list of references at the end of the volume. The compilation of so vast an amount of scattered material is difficult, and has been admirably done. The book is a valuable addition to bacteriological literature.

$$
\text { No. 3224, VoL. 128] }
$$

